\title{
ON ALGORITHM FOR NUMERICAL SOLUTION OF OPTIMAL MEASUREMENT PROBLEM USING LINEAR SPLINES
}

\author{
A. A. Ebel, South Ural State University, Chelyabinsk, Russian Federation, \\ ebelaa@susu.ru
}

We consider an algorithm for numerical solution of the optimal measurement problem using linear splines. The optimal measurement problem, which is based on the model of optimal control, is posed to restore the dynamically distorted signal. We propose to use a mixed-control problem for Leontief type systems in the development of numerical algorithm for solution of the optimal measurement problem. Furthermore, the use of linear splines at one of the algorithm steps reduces the amount of machine time required to find an approximate solution with a given accuracy.

Keywords: numerical algorithm of the optimal measurement problem; mixed control problem; optimal control; Leontief type system; Shoulter - Sidorov condition; Linear splines.

\section{Introduction}

The problem of the measured signal restoration is one of the most important problems in the theory of dynamical measurements. The mathematical model of the measuring device, the use of which allows to restore the dynamically distorted signals, was proposed and substantiated by A.L. Shestakov [1-4]. Consider the system

$$
\begin{gathered}
\dot{x}(t)=A x(t)+B u(t), \\
y(t)=C x(t),
\end{gathered}
$$

where matrices $A_{n \times n}, B_{n \times n}, C_{n \times m}$ model a structure of the measuring device, a vector function $x=x(t)$ is a state of the measurement device, and a vector function $u=u(t)$ is an input signal, a vector function $y=y(t)$ models a signal at the output of the measuring device. An approach, which gives more correct solutions and is based on the theory of automatic control, was proposed by A.L. Shestakov and developed by his learners [5]. One propose to build the generator model in the measuring device. This generator model generates signals, which are applied to the input of the measuring device. Note that such problems appear, for example, when one corrects a position of a spacecraft, where reactor engines, having small size, works over a very short time. Immediately after one switches on the engines, a peak input signal can not be measured due to a mechanical inertia of the measuring device. A.L. Shestakov, E.V. Soldatkina, M.N. Bizyaev, D.Yu. Iosiphov technically proposed the hypotheses about the resolving of signal recovery problem and realized them into engineering solutions [6-8].

Then to solve the problem of dynamically distorted signal recovering A.L. Shestakov and G.A. Sviridyuk proposed to use methods of optimal control theory and called the problem thus obtained as a problem of optimal measurement [9]. 
Using (1) - (2) one can get a model (3) with the initial condition (4), which in the case of the reversibility of a matrix $L$ is turned into the classical Cauchy condition.

$$
\begin{gathered}
L \dot{z}(t)=M z(t)+N u(t), \\
{\left[R_{\mu}^{L}(M)\right]^{p+1}\left(z(0)-z_{0}\right)=0,} \\
J(v)=\min _{u \in \mathrm{U}_{a d}} \sum_{q=0}^{1} \int_{0}^{\tau}\left\|C z^{(q)}(t, u)-C z_{0}^{(q)}(t)\right\| d t,
\end{gathered}
$$

where $z=\operatorname{col}\left(x_{1}, x_{2}, \ldots, x_{n}, y_{1}, y_{2}, \ldots, y_{m}\right), L=\left(\begin{array}{cc}\mathbb{I}_{n} & \mathbb{O} \\ \mathbb{O} & \mathbb{O}_{m}\end{array}\right), M=\left(\begin{array}{cc}A & \mathbb{O} \\ C & -\mathbb{I}_{m}\end{array}\right)$, $N=\left(\begin{array}{cc}B & \mathbb{O} \\ \mathbb{O} & \mathbb{O}_{m}\end{array}\right), C z, C z_{0}$ are simulated and observed values, which are used to restore of the distorted signal, respectively.

The problem of measurement recovery by the output signal is to minimize a functional (5), i.e. the smallest discrepancy between observed and simulated signal values, as well as between their derivatives, is achieved.

Note that the using of Showalter - Sidorov condition for numerical researches of the application problems does not require the agreement of the initial data. Notice that initial data verification is very difficult under using of the initial Cauchy conditions and imposes restrictions under the numerical solutions of optimal control problems. It allows to remove restrictions on the size of the matrices, which are included in the system [10].

A.V. Keller, E.I. Nazarova are interested in the numerical solution of the problem of optimal measurement with regard to the inertia of the measuring device. They considered an algorithm for numerical solution of the dynamic measurement problem as a hard optimal control problem [11]. Yu.V. Khudyakov, A.L. Shestakov proposed an algorithm for the numerical solution of the problem of dynamically distorted signal recovering with regard to an inertia as well as to resonances of a measuring device [12]. M.A. Sagadeeva investigates an optimal measurement for the model of the measuring device with regard to an determined multiplier effect [13].

G.A. Sviridyuk proposed to reduce such systems to the Leontief type equations, the solution of which is developed in Chelyabinsk mathematical school [14]. Leontief type equations are finite-dimensional analogue of the Sobolev type equations. An optimal control problem for Sobolev type equations was first posed and investigated by G.A. Sviridyuk and A.A. Efremov in $[15,16]$. The existence of unique solution of this problem with the initial Cauchy condition for the cases of relative boundedness and relative sectorialness of an operator was proved in theese papers. In [17] N.A. Manakova investigated sufficient conditions for the solvability of the optimal control problem for some semilinear Sobolev type equations with the initial Showalter - Sidorov condition. In addition, A.A. Zamyshlyaeva investigated the optimal control for higher-order Sobolev type equations [18]. In [19] A.V. Keller and M.A. Sagadeeva proved an existence and uniqueness of solutions of optimal control problem for non-stationary equation of Sobolev type with strong $(L, p)$-radial operator. An optimal control of solutions of the initial-final problem for the Sobolev type equation was investigated by A.G. Dylkov in [20]. B работе [21] Исламовой А.Ф. A mixed control problem of distributed systems with functional, which is weak with respect to state function, was considered by A.F. Islamova in [21] . 
A solution of the optimal measurement problem as a mixed optimal control problem is provided in the first part of the article. An algorithm of numerical solution to the optimal measurement problem using splines is proposed in the second part.

\section{A Solution of the Optimal Measurement Problem as a Mixed Optimal Control Problem}

Consider spaces of states and controls

$$
\begin{gathered}
\mathfrak{Z}=H^{1}\left(\mathbb{R}^{n}\right)=\left\{z \in L_{2}\left((0 ; \tau) ; \mathbb{R}^{n}\right): \dot{z} \in L_{2}\left((0 ; \tau) ; \mathbb{R}^{n}\right)\right\} \\
\mathfrak{U}=H^{p+1}\left(\mathbb{R}^{n}\right)=\left\{u \in L_{2}\left((0 ; \tau) ; \mathbb{R}^{n}\right): u^{(p+1)} \in L_{2}\left((0 ; \tau) ; \mathbb{R}^{n}\right)\right\}, \mathfrak{U}^{0}=H^{1}\left(\mathbb{R}^{n}\right) .
\end{gathered}
$$

Let $\mathfrak{U}_{a d}, \mathfrak{U}_{a d}^{0}$ be compact and convex sets of admissible controls in $\mathfrak{U}, \mathfrak{U}^{0}$, respectively.

To solve the mixed hard control problem we search $\left(w_{0}, v, z\left(w_{0}, v\right)\right) \in \mathfrak{U}_{a d}^{0} \times \mathfrak{U}_{a d} \times \mathfrak{Z}$ satisfying almost everywhere the Leontief type system

$$
\begin{gathered}
L \dot{z}(t)=M z(t)+N u(t) \\
{\left[R_{\mu}^{L}(M)\right]^{p+1}\left(z(0)-w_{0}\right)=0} \\
J\left(v_{0}, v\right)=\min _{\left(w_{0}, u\right) \in \mathfrak{U}_{a d}^{0} \times \mathfrak{U}_{a d}} \sum_{q=0}^{1} \int_{0}^{\tau}\left\|C z^{(q)}\left(t, w_{0}, u\right)-C w_{0}^{(q)}(t)\right\| d t,
\end{gathered}
$$

where $z=\operatorname{col}\left(x_{1}, x_{2}, \ldots, x_{n}, y_{1}, y_{2}, \ldots, y_{m}\right), x=\operatorname{col}\left(x_{1}, x_{2}, \ldots, x_{n}\right), y=\operatorname{col}\left(y_{1}, y_{2}, \ldots, y_{m}\right)$, $u=\operatorname{col}\left(u_{1}, u_{2}, \ldots, u_{n}\right)$ are vector-functions of states, measurements and observations; $C z$, $C w_{0}$ are simulated and real observations, using to restore a distorted signal, respectively.

Problem (3) - (5) in Hilbert spaces and in a more general formulation was considered in [22]. Therefore, we give the following result for the finite-dimensional case without proof.

Theorem 1. Let matrix $M(L, p)$ be regular, $p \in\{0\} \cup \mathbb{N}$, and $\operatorname{det} M \neq 0$. Then there is a unique solution $\left(w_{0}, v, z\left(w_{0}, v\right)\right) \in \mathfrak{U}_{a d}^{0} \times \mathfrak{U}_{a d} \times \mathfrak{Z}$ is a minimum point of functional (5), and $z\left(v_{0}, v\right)$ is a solution of problem (3), (4) and is defined by the formula

$$
\begin{aligned}
z\left(w_{0}, v(t)\right) & =\lim _{k \rightarrow+\infty} z_{k}\left(w_{0}, v(t)\right)=\lim _{k \rightarrow+\infty}\left[Z_{k}^{t} w_{0}-\right. \\
& \left.-\sum_{q=0}^{p}\left(M^{-1}\left(I-Q_{k}\right) L\right)^{q} M^{-1}\left(I-Q_{k}\right)(N v(t))^{(q)}+\int_{0}^{\tau} R_{k}^{t-s} Q_{k} N v(s) d s\right]
\end{aligned}
$$

where

$$
\begin{gathered}
Z_{k}^{t}=\left(\left(L-\frac{t}{k} M\right)^{-1} L\right)^{k(p+1)}, \quad Q_{k}=\left(k L_{k}^{L}(M)\right)^{p+1}, \\
R_{k}^{t}=\left(\left(L-\frac{t}{k} M\right)^{-1} L\right)^{k(p+1)-1} \cdot\left(L-\frac{t}{k} M\right)^{-1} \cdot
\end{gathered}
$$

Consider quality functional (8) on the compact convex sets $\mathfrak{U}_{a d} \subset \mathfrak{U}, \mathfrak{U}_{a d}^{0} \subset \mathfrak{U}^{0}$. Note that this functional is a continuous function by the construction. By Weierstrass theorem 
for continuous functions on a compact, quality functional (8) is bounded function on $\mathfrak{W}_{a d}=\mathfrak{U}_{a d}^{0} \times \mathfrak{U}_{a d}$. A convex is an important property of function in the study of the convergence.

Theorem 2. [23] Let matrix $M(L, p)$ be regular, $\mathrm{p} \in\{0\} \cup \mathbb{N}$, $\operatorname{det} \mathrm{M} \neq 0$, and sets $\mathfrak{U}_{a d} \subset \mathfrak{U}, \mathfrak{U}_{a d}^{0} \subset \mathfrak{U}^{0}$ be compact and convex. Then functional (8) is strongly convex function on $\mathfrak{W}_{a d}=\mathfrak{U}_{a d}^{0} \times \mathfrak{U}_{a d}$.

Let $w(t)=\left(w_{0} ; v(t)\right) \in \mathfrak{W}_{a d}$. Denote an exact and an approximate solution of problem $(6)-(8)$ as $(w(t), z(w(t)))$ and $\left(\tilde{w}_{k}^{\ell}(t), \tilde{z}_{k}^{\ell}\left(\tilde{w}_{k}^{\ell}(t)\right)\right)$, respectively. Here $J_{k}\left(\tilde{w}_{k}^{\ell}\right)$ is an approximate value of the functional.

Theorem 3. [24] Let matrix $M(L, p)$ be regular, $p \in\{0\} \cup \mathbb{N}$, and $\operatorname{det} M \neq 0$. A functional

$$
J(w)=\sum_{q=0}^{1} \int_{0}^{\tau}\left\|C z^{(q)}(t, w)-C w_{0}^{(q)}(t)\right\| d t
$$

is continuous, strongly convex, bounded on the convex compact set $\mathfrak{U}$. Let $(w(t), z(w(t)))$ be exact solution of (3)-(5), and $\left(\tilde{w}_{k}^{\ell}(t), \tilde{z}_{k}^{\ell}\left(\tilde{w}_{k}^{\ell}(t)\right)\right)$ be approximate one. Then a sequence $\left\{\tilde{w}_{k}^{\ell}\right\}$ converges to $\{w\}$ in the norm $\mathfrak{U}$, a sequence $\left\{\tilde{z}_{k}^{\ell}\right\}$ converges to $\{z\}$ in the norm $\mathfrak{Z}$ for $k \rightarrow \infty, \ell \rightarrow \infty$ such that $J_{k}\left(\tilde{w}_{k}^{\ell}\right) \rightarrow J(w)$, and an inequality $q\left\|\tilde{w}_{k}^{\ell}-w^{\ell}\right\| \leq J_{k}\left(\tilde{w}_{k}^{\ell}\right)-J(w)$ holds.

\section{An Algorithm for Numerical Solution of the Optimal Measurement Problem Using Linear Splines}

Preliminary calculations and enter of data are performed on the 1st stage. This stage is similar to the previously considered algorithms for numerical solution of the optimal measurement problem $[11,25]$.

STEP 1. Calculate $\operatorname{det} M$. Check that its value is different from zero with an accuracy $\varepsilon=10^{-30}$. In the case of $\operatorname{det} M=0$ it is necessary to substitute $y=e^{\lambda t} x$ and continue to find a solution.

STEP 2. Calculate an order of the pole $p=n-q$, where $q=\operatorname{deg} \operatorname{det}(\mu L-M)$.

STEP 3. Calculate number $K$ from which one can calculate an approximate solution $K=\max \left\{k_{1}, k_{2}\right\}$. Here $k_{1}=\frac{1}{\alpha} \sum_{i=0}^{q}\left|a_{i}\right|+1, k_{2}=\frac{1}{\alpha p^{p}} \sum_{i=0}^{q}\left|a_{i}\right|(p+1)^{n-i}+1$, where $\alpha=\max \left\{1, \frac{1}{\left|a_{q}\right|} \sum_{i=0}^{q}\left|a_{i}\right|\right\}$.

A search for an interim solution is performed on the 2 stage. Earlier a zero solution as a initial one was used in algorithms of solution search. An intermediate solution is searched in the form: $\bar{v}^{l}(t)=\operatorname{col}\left(\sum_{j=0}^{l} \bar{a}_{1 j} t^{j}, \ldots, \sum_{j=0}^{l} \bar{a}_{n j} t^{j}\right)$.

STEP 4. Determine points $t_{i}: t_{i}=t_{0}+\sum_{j=1}^{i} \Delta_{j}, i=1, \ldots, n$, and $t_{n}=\tau$.

STEP 5. Enter observation values $y_{0}=y\left(t_{0}\right), y_{1}=y\left(t_{1}\right)$ using natural experiment data.

STEP 6. Perform linear interpolation by the points $\left(t_{0} ; y_{0}\right)$ and $\left(t_{1} ; y_{1}\right)$.

STEP 7 . Find measurement vector-function $\tilde{v}_{1}=\tilde{a}_{1}^{0}+\tilde{a}_{1}^{1} t_{1}, t \in\left[t_{0}, t_{1}\right]$ as a solution of the mixed control problem.

STEP 8. Define a state of the system $\tilde{z}_{1}=\tilde{z}\left(t_{1}\right)$ by $\tilde{v}_{1}=\tilde{a}_{1}^{0}+\tilde{a}_{1}^{1} t_{1}$. 


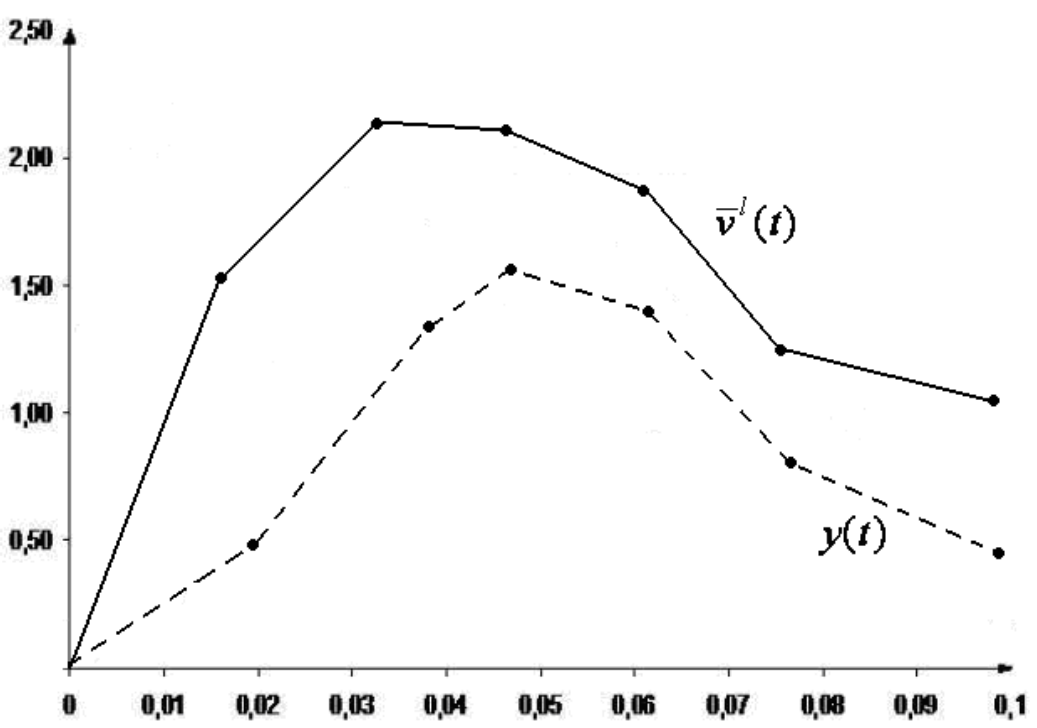

Fig. 1. Linear interpolation

Steps 9-11 form a cycle through $i=2, \ldots, n$, and $t_{n}=\tau$ (result on Fig. 1).

STEP 9. Perform linear interpolation by the points $\left(t_{i-1} ; y_{i-1}\right),\left(t_{i} ; y_{i}\right)$ and obtain $\tilde{y}_{i}=\tilde{y}\left(t_{i}\right)$.

STEP 10. Find measurement vector-function of solution of optimal control problem in the form of $\tilde{v}_{i}=\tilde{a}_{i}^{0}+\tilde{a}_{i}^{1} t_{i}$, and $\tilde{a}_{i}^{0}=\tilde{v}_{i-1}\left(t_{i-1}\right)$.

STEP 11 . Find a state of the system $\tilde{z}_{i}=\tilde{z}\left(t_{i}\right)$ by measurement vector-function $\tilde{v}_{i}=\tilde{a}_{i}^{0}+\tilde{a}_{i}^{1} t_{i}$.

STEP 12. Perform interpolation by $\left(t_{i}, \tilde{v}_{i}\right)$ by Lagrange polynomial: $\bar{v}^{l}(t)=\operatorname{col}\left(\sum_{j=0}^{l} \bar{a}_{1 j} t^{j}, \ldots, \sum_{j=0}^{l} \bar{a}_{n j} t^{j}\right)$.

A search of proximate solution is performed only on the 3th stage.

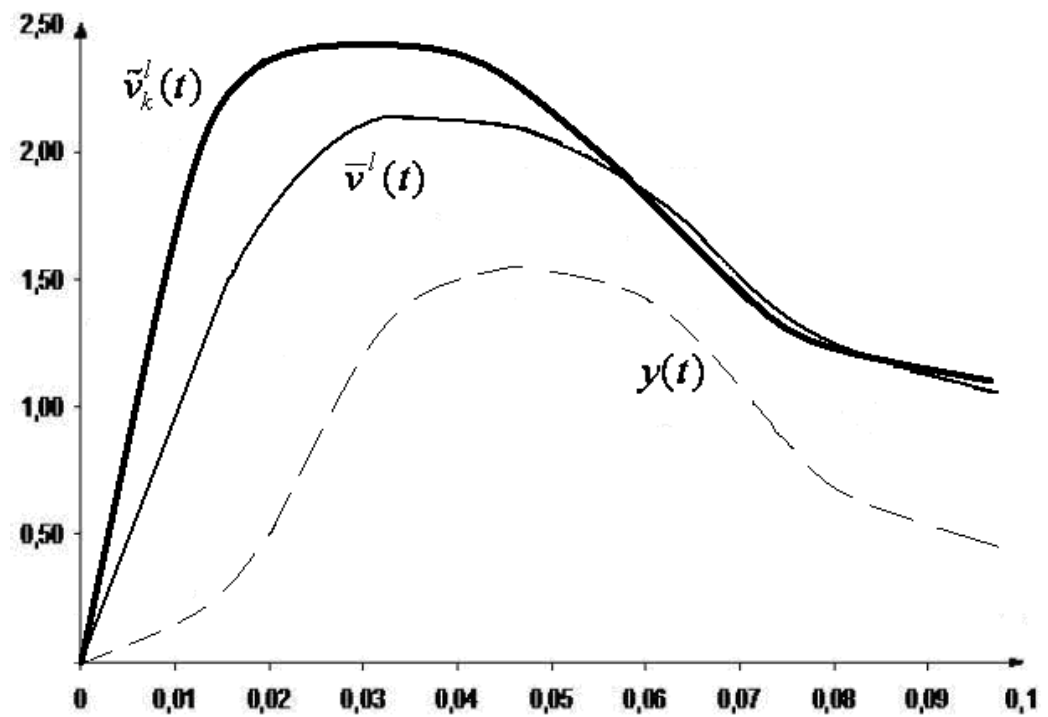

Fig. 2. Result of calculations 
STEP 13. For given $\eta$ and integration interval $[0, \tau]$ calculate weights $\omega_{j}$ and nodes $s_{j}$ for Gauss quadrature formula $\int_{0}^{\tau} f(x) d x \approx \frac{\tau}{2} \sum_{j=1}^{2 \eta+1} \omega_{j} f\left(\frac{\tau}{2}+\frac{\tau}{2} s_{j}\right)$, where nodes $s_{j}$ are zeros of Legendre polynomial $P_{n}(t)=\frac{1}{2^{n} n !} \cdot \frac{d^{n}}{d t^{n}}\left(\left(t^{2}-1\right)^{2}\right), n=0,1$, and weights are determined by the next formula $\omega_{j}=\frac{2}{\left[P_{n}^{\prime}\left(s_{j}\right)\right]^{2}\left(1-s_{j}\right)^{2}}$.

STEP 14. Calculate $z_{k}(t)$ и $J_{k}\left(z_{k}\right)$ in given points $\vartheta_{j} \in[0, \tau]$ for the values $\bar{a}_{i j}$, which were found on the 2 stage from $\bar{v}^{l}(t)=\operatorname{col}\left(\sum_{j=0}^{l} \bar{a}_{1 j} t^{j}, \ldots, \sum_{j=0}^{l} \bar{a}_{n j} t^{j}\right)$.

STEP 15. Find a minimum of the functional $J\left(\tilde{v}_{k}^{l}\right)$ and a minimum point $\tilde{v}_{k}^{l}=\operatorname{col}\left(\sum_{j=0}^{l} a_{1 j}^{*} t^{j}, \ldots, \sum_{j=0}^{l} a_{n j}^{*} t^{j}\right)$.

Consider a process for finding of values of coefficients $\widehat{a_{i j}^{\rho}}$ and an approximate value of the quality functional $J_{k}\left(\tilde{v}_{k}^{l}\right)=J_{k}\left(\widehat{a_{i j}^{\rho}}\right)$ within one iteration of the main calculation. Substitute $a_{i j}=\widehat{a_{i j}}$ and $J=J_{k}\left(\widehat{a_{i j}}\right)$ for iteration $\rho-1$.

The following steps are carried out for each $i$-th component :

1) $a_{10}^{(1+)}=a_{10}+h_{10}$ and $a_{10}^{(1-)}=a_{10}-h_{10}$. Calculate the functionals $J_{1}^{(1+)}$ и $J_{1}^{(1-)}$.

If $J_{1}^{(1+)}>J$ and $J_{1}^{(1-)}>J$, then $\widehat{a_{10}^{p}}=a_{10}^{1}$ and go to the element $a_{20}$.

2) If $J_{1}^{(1+)}<J\left(J_{1}^{(1-)}<J\right)$, then

$J_{1}^{(1 s)}=J_{1}^{(1+)}\left(J_{1}^{(1 s)}=J_{1}^{(1-)}\right)$ and $a_{10}^{(1 s)}=a_{10}^{(1+)}\left(a_{10}^{(1 s)}=a_{10}^{(1-)}\right)$.

Then, change $a_{10}^{(1 s)}: a_{10}^{(2+)}=a_{10}^{(1 s)}+h_{20}$ and $a_{10}^{(2-)}=a_{10}^{(1 s)}-h_{20}$, where $h_{20}=r \cdot h_{10}$.

If $J_{1}^{(2+)}>J_{1}^{(1 s)}$ and $J_{1}^{(2-)}>J_{1}^{(1 s)}$, then $\widehat{a_{10}^{p}}=a_{10}^{(1 s)}, J=J_{1}^{(1 s)}$ and go to the element $a_{20}$.

3) If $J_{1}^{(2+)}<J_{1}^{(1 s)}\left(J_{1}^{(2-)}<J_{1}^{(1 s)}\right)$, then

$J_{1}^{(2 s)}=J_{1}^{(2+)}\left(J_{1}^{(2 s)}=J_{1}^{(2-)}\right)$ and $a_{10}^{(2 s)}=a_{10}^{(2+)}\left(a_{10}^{(2 s)}=a_{10}^{(2-)}\right)$.

Then, change $a_{10}^{(2 s)}$, etc.

The procedure of elements change is performed over all elements of the first row. Then, determine a value $\widehat{a_{1 \zeta}}=\widehat{a_{1 j}}$ for which value $J$ was obtained after a cycle over elements of the first row. $\widehat{a_{1 \zeta}}$ is the unique array element, which is changed. After changing of the element $\widehat{a_{1 \zeta}}$ of the first row go to a cycle over elements of the second row, etc. An array thus obtained is used in future calculations. Note that during the calculation a step value $\Delta_{i}$, which gives the lowest value of the quality functional, is fixed for each row. Subsequent iterations of changing of $i$ th row elements start with $\Delta_{i}$. It significantly increases the speed of calculations.

The main calculation is as long as the condition $\left|J_{k}\left(\widehat{a_{i j}^{\rho}}\right)-J_{k}\left(\widehat{a_{i j}^{\rho-1}}\right)\right|<\varsigma$ does not hold. After required accuracy is achived, one calculate a minimum of functional $J\left(\tilde{v}_{k}^{l}\right)$ and a minimum point $\tilde{v}_{k}^{l}=\operatorname{col}\left(\sum_{j=0}^{l} a_{1 j}^{*} t^{j}, \ldots, \sum_{j=0}^{l} a_{n j}^{*} t^{j}\right)$.

STEP 16. Calculate value $\tilde{z}_{k}^{l}=z_{k}\left(\tilde{v}_{k}^{0} ; \tilde{v}_{k}^{l} ; t\right)$.

The introduction of the new stage 2 significantly reduces the number of iterations on the 3th stage (Fig. 2). Finally, it leads to reducing of the computation time needed to solve the optimal measurement problem. 


\section{References}

1. Shestakov A.L. Dynamic Accuracy of the Transmitter with a Corrective Device as a Sensor. Metrology, 1987, no. 2. pp. 26-34. (in Russian)

2. Shestakov A.L. Transmitter of Dynamic Parameters with Iterative Signal Recovery Principle. Devices and Control Systems, 1992, no. 10. pp. 23-24. (in Russian)

3. Shestakov A.L., Bizyaev M.N. Restoration of Dynamically Distorted Signals of Test and Measurement Systems Using Sliding Sodels. Izvestiya RAN. Energetics, 2004, no. 6. pp. 119-130. (in Russian)

4. Shestakov A.L., Volosnikov A.S. Neural Network Dynamic Model of Measuring System with Filtration of the Restored Signal. Bulletin of SUSU. Series: Computer Technology, Control, Radio Electronics, 2006, no. 14 (69), issue 4. pp. 16-20. (in Russian)

5. Shestakov A.L., Sviridyuk G.A. A New Approach to the Measurement of Dynamically Distorted Signals. Bulletin of the South Ural State University. Series: Mathematical Modelling, Programming and Computer Software, 2010, no. 16 (192). pp. 116-120. (in Russian)

6. Soldatkina E.V. [Algorithms for Adaptation of the Parameters of the Measuring System to a Minimum Dynamic Error Evaluation]. Dissertation of PhD. (Technical Sciences). Chelyabinsk, 2000. (in Russian)

7. Bizyaev M.N. [Dynamic Models and Algorithms of Restoring of Dynamically Distorted Signals of Measuring Systems in a Sliding Mode]. Dissertation of PhD. (Technical Sciences). Chelyabinsk, 2004. (in Russian)

8. Josephov D.Yu. [Dynamic Models and Algorithms of Restoring of Measuring Systems Signals with an Observed State Coordinates Vector]. Dissertation of PhD. (Technical Sciences). Chelyabinsk, 2007. (in Russian)

9. Shestakov A.L., Sviridyuk G.A. Optimal Measurement of Dynamically Distorted Signals. Bulletin of the South Ural State University. Series: Mathematical Modelling, Programming and Computer Software, 2011, no. 17 (234), issue 8. pp. 70-75.

10. Zagrebina S.A. On the Showalter - Sidorov Problem. Russian Mathematics (IzVUZ). Mathematics, 2007, no. 3. pp. 22-28. (in Russian)

11. Keller A.V., Nazarova E.I. Optimal Measurement Problem: a Numerical Solution, a Program Algorithm. Bulletin of Irkutsk State University. Series: Mathematics, 2011, no. 3. pp. 74-82. (in Russian)

12. Khudyakov Yu.V., Shestakov A.L. A Numerical Study Algorithm of the ShestakovSviridyuk Model of Measuring Transducer with Inertia and Resonances. Mathematical Notes NEFU, 2013, vol. 20, no. 2. pp. 211-221. (in Russian)

13. Sagadeeva M.A., Khudyakov Yu.V. On Optimal Measurement for Model of the Measurement Transducer Considering the Determined Multiplicative Effect. Book of XII National Conference on Control Problems, 2014, pp. 2240-2245. (in Russian) 
14. Sviridyuk G.A., Fedorov V.E. Linear Sobolev Type Equations and Degenerate Semigroups of Operators. Utrecht; Boston, VSP, 2003.

15. Sviridyuk G.A., Efremov A.A. Optimal Control of Linear Sobolev Type Equations with Respect to p-Sectorial Operators. Differential equations, 1995, vol. 31. pp. 1912-1919. (in Russian)

16. Sviridyuk G.A., Efremov A.A. An Optimal Control Problem for a Class of Linear Equations of Sobolev Type. Russian Math. (Iz.VUZ), 1997, vol. 40, no. 12. pp. 72-80

17. Manakova N.A., Bogonos E.A. Optimal Control of Solutions of the Showalter - Sidorov Problem for a Sobolev Type Equation. Bulletin of Irkutsk State University. Series: Mathematics, 2010, vol. 3, no. 1. pp. 42-53. (in Russian)

18. Zamyshlyaeva A.A. Mathematical Models Sobolev Type of the Highier Order. Bulletin of the South Ural State University. Series: Mathematical Modelling, Programming and Computer Software, 2014, vol. 7, no. 2. pp. 5-28. doi: 10.14529/mmp140201

19. Keller A.V., Sagadeeva M.A. Numerical Solution of Optimal and Hard Control Problems for a Nonstationary Leontief Type System. Scientific Bulletin of Belgorod State University. Series: Mathematics. Physics, 2013, vol. 32, no. 19 (162). pp. 57-66. (in Russian)

20. Manakova N.A., Dyl'kov A.G. Optimal Control of the Solutions of the Initial-Finish Problem for the Linear Hoff Model. Mathematical Notes, 2013, vol. 94, no. 1-2. pp. 220-230. doi: 10.1134/S0001434613070225

21. Plekhanova M.V., Islamova A.F. The Mixed Control Problem for a Class of Linear Sobolev Type Equations. Vestnik CSU, 2010, no. 23. pp. 49-58. (in Russian)

22. Keller A.V., Ebel A.A. The Existence of a Unique Solution to a Mixed Control Problem for Sobolev Type Equations. Bulletin of the South Ural State University. Series: Mathematical Modelling, Programming and Computer Software, 2014, vol. 7, no. 3. pp. 121-127. doi: 10.14529/mmp140313

23. Ebel A.A. The Properties of Functional of Mixed Control Problems for Leontief Type System. South Ural Youth School on Mathematical Modelling, 2015, pp. 203-206. (in Russian)

24. Keller A.V., Ebel A.A. A Numerical Method for Solving of Mixed Control Problems for Leontief Type Systems. Bulletin of SUSU. Series: Mathematics. Mechanics. Physics, 2015, vol. 7, no. 4, pp. 37-45. doi: 10.14529/mmph150405 (in Russian)

25. Keller A.V., Sagadeeva M.A. An Optimal Measurement Problem for a Measuring Device Model with Deterministic Multiplicative Effect and Inertia Bulletin of the South Ural State University. Series: Mathematical Modelling, Programming and Computer Software, 2014, vol. 7, no. 1. pp. 134-138. doi: 10.14529/mmp140111 (in Russian)

Andrej A. Ebel, Senior Lecturer, Department of Differential and Stochastic Equations, South Ural State University (Chelyabinsk, Russian Federation), ebelaa@susu.ru 
Received February 26, 2016

\title{
ОБ АЛГОРИТМЕ ЧИСЛЕННОГО РЕШЕНИЯ ЗАДАЧИ ОПТИМАЛЬНОГО ИЗМЕРЕНИЯ С ИСПОЛЬЗОВАНИЕМ ЛИНЕЙНЫХ СПЛАЙНОВ
}

\author{
А.А. Эбель
}

В работе рассмотрен алгоритм численного решения задачи оптимального измерения с использованием линейных сплайнов. Задача оптимального измерения, в основе которой модель оптимального управления, ставится для восстановления динамически искаженного сигнала. В статье предложено использовать задачу смешанного управления для систем леонтьевского типа в разработке численного алгоритма решения задачи оптимального измерения. Кроме того, использование линейных сплайнов на одном из этапов алгоритма позволяет уменьшить количество машинного времени, необходимого для нахождения приближенного решения с заданной точностью.

Ключевые слова: численный алгоритм задачи оптимального измерения; задача смешанного управления; оптимальное управление; система леонтъевского типа; условие Шоуолтера - Сидорова; линейные сплайны.

\section{Литература}

1. Шестаков, А.Л. Динамическая точночть измерительного преобразователя с корректирующим устройством в виде датчика / А.Л. Шестаков // Метрология. 1987. - № 2. - C. 26-34.

2. Шестаков, А.Л. Измерительный преобразователь динамических параметров с итерационным принципом восстановления сигнала / А.Л. Шестаков // Приборы и системы управления. - 1992. - № 10. - С. 23-24.

3. Шестаков, А.Л. Восстановление динамически искаженных сигналов испытательно-измерительных систем методом скользящих режимов / А.Л. Шестаков, М.Н. Бизяев // Известия РАН. Энергетика. - 2004. - № 6. - С. 119-130.

4. Шестаков, А.Л. Нейросетевая динамическая модель измерительной системы с фильтрацией восстанавливаемого сигнала / А.Л. Шестаков, А.С. Волосников // Вестник ЮУрГУ. Серия: Компьютерные технологии, управление, радиоэлектроника. - 2006. - № 14 (69), вып. 4. - С. 16-20.

5. Шестаков, А.Л. Новый подход к измерению динамически искаженных сигналов / А.Л. Шестаков, Г.А. Свиридюк // Вестник ЮУрГУ. Серия: Математическое моделирование и программирование. - 2010. - № 16 (192). - С. 116-120.

6. Солдаткина, Е.В. Алгоритмы адаптации параметров измерительной системы к минимуму оценки динамической погрешности: дисс. ... канд. техн. наук / Е.В. Солдаткина. - Челябинск: ЮУрГУ, 2000. 
7. Бизяев, М.Н. Динамические модели и алгоритмы восстановления динамически искаженных сигналов измерительных систем в скользящем режиме: дисс. ... канд. техн. наук / М.Н. Бизяев. - Челябинск: ЮУрГУ, 2004.

8. Иосифов, Д.Ю. Динамические модели и алгоритмы восстановления сигналов измерительных систем с наблюдаемым вектором координат состояния: дисс. ... канд. техн. наук / Д.Ю. Иосифов. - Челябинск: ЮУрГУ, 2007.

9. Шестаков, А.Л. Оптимальное измерение динамически искаженных сигналов / А.Л. Шестаков, Г.А. Свиридюк // Вестник ЮУрГУ. Серия: Математическое моделирование и программирование. - 2011. - № 17 (234), вып. 8. - С. 70-75.

10. Загребина, С.А. О задаче Шоуолтера - Сидорова / С.А. Загребина // Известия высших учебных заведений. Математика. - 2007. - № 3. - С. 22-28.

11. Келлер, А.В. Задача оптимального измерения: численное решение, алгоритм программы / А.В. Келлер, Е.И. Назарова // Известия Иркутского государственного университета. Серия: Математика. - 2011. - № 3. - С. 74-82.

12. Худяков, Ю.В. Алгоритм численного исследования модели Шестакова - Свиридюка измерительного устройства с инерционностью и резонансами / Ю.В. Худяков, А.Л. Шестаков // Математические заметки СВФУ. - 2013. - Т. 20, № 2. C. $211-221$.

13. Сагадеева, М.А. Об оптимальном измерении для модели измерительного устройства с учетом детерминированного мультипликативного воздействия / М.А. Сагадеева, Ю.В. Худяков // Сборник XII Всероссийского совещания по проблемам управления. - 2014. - С. 2240-2245.

14. Sviridyuk, G.A. Linear Sobolev Type Equations and Degenerate Semigroups of Operators / G.A. Sviridyuk, V.E. Fedorov. - Utrecht; Boston: VSP, 2003. - 179 p.

15. Свиридюк, Г.А. Оптимальное управление линейными уравнениями типа Соболева с относительно р-секториальными операторами / Г.А. Свиридюк, А.А. Ефремов // Дифференциальные уравнения. - 1995. - Т. 31, № 11. - С. 1912-1919.

16. Свиридюк, Г.А. Задача оптимального управления для одного класса линейных уравнений типа Соболева / Г.А. Свиридюк, А.А. Ефремов // Известия вузов. Математика. - 1996. - Т. 40, № 12. - С. 75-83.

17. Манакова, Н.А. Оптимальное управление решениями задачи Шоуолтера-Сидорова для одного уравнения соболевского типа / Н.А. Манакова, Е.А. Богонос // Известия Иркутского государственного университета. Серия: Математика. 2010. - T. 3, № 1. - C. 42-53.

18. Замышляева, А.А. Математические модели соболевского типа высокого порядка / А.А. Замышляева // Вестник ЮУрГУ. Серия: Математическое моделирование и программирование. - 2014. - Т. 7, № 2. - С. 5-28. 
19. Келлер, А.В. Численное решение задач оптимального и жесткого управления для одной нестационарной системы леонтьевского типа / А.В. Келлер, М.А. Сагадеева // Научные ведомости Белгородского государственного университета. Серия: Математика. Физика. - 2013. - Т. 32, № 19 (162). - С. 57-66.

20. Manakova, N.A. Optimal Control of the Solutions of the Initial-Finish Problem for the Linear Hoff Model / N.A. Manakova, A.G. Dyl'kov // Mathematical Notes. - 2013. T. 94, № 1-2. - C. 220-230.

21. Плеханова, М.В. Задача со смешанным управлением для одного класса линейных уравнений соболевского типа / М.В. Плеханова, А.Ф. Исламова // Вестник Челябинского государственного университета. - 2010. - № 23. - С. 49-58.

22. Keller, A.V. The Existence of a Unique Solution to a Mixed Control Problem for Sobolev Type Equations / A.V. Keller, A.A. Ebel // Вестник ЮУрГУ. Серия: Математическое моделирование и программирование. - 2014. - Т. 7, № 3. - С. 121-127.

23. Эбель, А.А. О свойствах функционала задач смешанного управления смешанного управления для систем леонтьевского типа / А.А. Эбель // Южно-Уральская молодежная школа по математическому моделированию: сб. тр. II Всеросс. науч.практ. конф. - 2015. - С. 203-206.

24. Келлер, А.В. Численный метод решения задач смешанного управления для систем леонтьевского типа / А.В. Келлер, А.А. Эбель // Вестник ЮУрГУ. Серия: Математика. Механика. Физика. - 2015. - Т. 7, № 4. - С. 37-45.

25. Келлер, А.В. Задача оптимального измерения для модели измерительного устройства с детерминированным мультипликативным воздействием и инерционностью / А.В. Келлер, М.А. Сагадеева // Вестник ЮУрГУ. Серия: Математическое моделирование и программирование. - 2014. - Т. 7, № 1. - С. 134-138.

Эбель Андрей Александрович, старший преподаватель, кафедра дифференииальных и стохастических уравнений, Южно-Уральский госудаственный университет (2. Челябинск, Российская Федерачия), ebelaa@susu.ru

Поступила в редакцию 26 февраля 2016 г. 